\title{
Forløsningsmetode påvirker ikke mental helse
}

Valg av forløsningsmetode har ingen betydning for utvikling av angst og depresjon etter fødselen. Det viser en norsk studie.

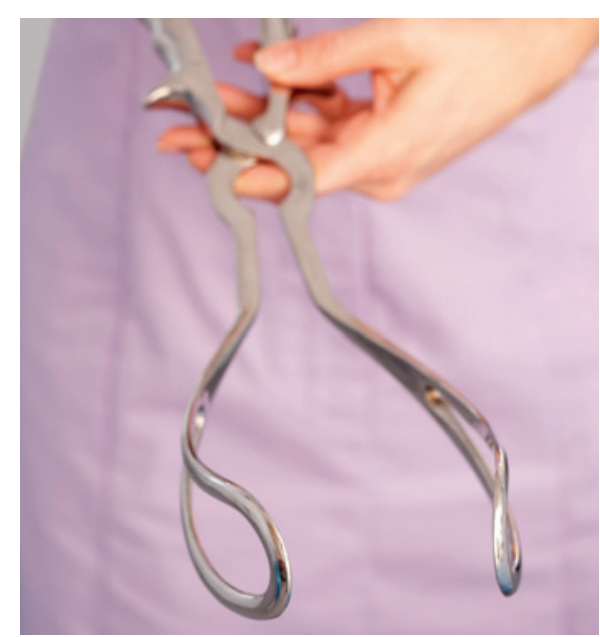

Illustrasjonsfoto Sciencephoto/Scanpix
Elektivt keisersnitt utføres av og til på psykososial indikasjon når obstetrisk indikasjon ikke foreligger. Har dette noen betydning for kvinnens mentale helse etter fødsel?

Vi har undersøkt 55814 gravide kvinner i den norske mor og barn-undersøkelsen (1). Kvinnene, som ble rekruttert i perioden 1998-2008, besvarte et spørreskjema i 30 . svangerskapsuke og seks måneder etter fødselen. Ytterligere opplysninger om graviditet og fødsel ble hentet fra Medisinsk fødselsregister.

Angst og depresjon ble kartlagt med Hopkins Symptom Checklist, et spørreskjema som er et godt mål på angst- og depresjonssymptomer. Forløsningsmetode ble inndelt i normal vaginalforløsning, operativ vaginalforløsning (dvs. vakuumforløsning og tangforløsning), akutt keisersnitt og elektivt keisersnitt. Vi kontrollerte for fødselskomplikasjoner, paritet, mors alder, utdanningsnivå og ønske om keisersnitt.

Det var ingen sammenheng mellom forløsningsmetode og endring $i$ angst- og depresjonssymptomer fra 30 . svangerskapsuke til seks måneder etter fødsel. Det var heller ingen sammenheng mellom forløsningsmetode og forekomst av angst- og depresjonssymptomer etter fødselen. Det var først og fremst symptomer på angst og depresjon under svangerskapet som hadde betydning for om kvinnen hadde angst og depresjon etter fødselen.

Studien viser at bekymring for mors psykiske helse etter fødsel i seg selv ikke bør være en indikasjon for å utføre elektivt keisersnitt. Den viser også at akutte operative forløsninger ikke fører til mer angst eller depresjon etter fødselen.

\section{Samantha Salvesen Adams \\ samantha.s.adams@ahus.no \\ Akershus universitetssykehus \\ Litteratur \\ 1. Adams S, Eberhard-Gran M, Sandvik A et al. Mode of delivery and postpartum emotional distress: a cohort study of 55814 women. BJOG 2011; DOI: 10.1111/j.1471-0528.2011.03188.x.}

\section{Overvektige barn har økt risiko for hjertesykdom}

\section{Overvekt hos barn er forbundet med økt risiko for kardiovaskulær sykdom, men risikoen kan reduseres dersom de oppnår normalvekt i voksen alder.}

I en ny metaanalyse har man undersøkt hvordan kroppsmasseindeks i barnealder påvirker kardiovaskulær risiko i voksen alder (1). Analysen var basert på fire prospektive kohortstudier med rundt 6300 personer som ble fulgt fra 3-18 års alder. Gjennomsnittlig oppfølgingstid var 23 år. De som var fete eller overvektige både som barn og voksne, hadde økt risiko for type 2-diabetes (RR 5,4), hypertensjon ( $R R$ 2,7), dyslipidemi med bl.a. økt LDL-nivå (RR 1,8) og økt intima media-tykkelse (RR 1,7) sammenliknet med dem som var normalvektige gjennom hele studieperioden.

Imidlertid hadde de med overvekt eller fedme i barnealder og som ble normalvektige $\mathrm{i}$ voksen alder, omtrent samme risiko som dem som var normalvektige både som barn og voksne. Dette gjaldt med ett unntak: Overvekt i barnealder var fortsatt forbundet med risiko for hypertensjon, selv hos dem som ble normalvektige (RR 1,5).

- Denne metaanalysen gir sterke holde- punkter for at vellykket behandling av overvekt og fedme hos barn kan redusere risikoen for alvorlige fedmerelaterte følgesykdommer senere i livet, sier Jøran Hjelmesæth, leder ved Senter for sykelig overvekt i Helse Sør-Øst.

- Analysen har imidlertid flere svakheter og den må oppfattes som hypotesegenererende. Likevel bør de gode resultatene kunne brukes som en ekstra motivasjon til å styrke arbeidet med forebygging og behandling av overvekt hos barn, både på samfunns- og individnivå, sier Hjelmesæth.

\section{Merete Kile Holtermann}

merete.holtermann@legeforeningen.no

Tidsskriftet

\section{Litteratur}

1. Juonala M, Magnussen CG, Berenson GS et al. Childhood adiposity, adult adiposity, and cardiovascular risk factors. N Engl J Med 2011 : 365: 1876-85.

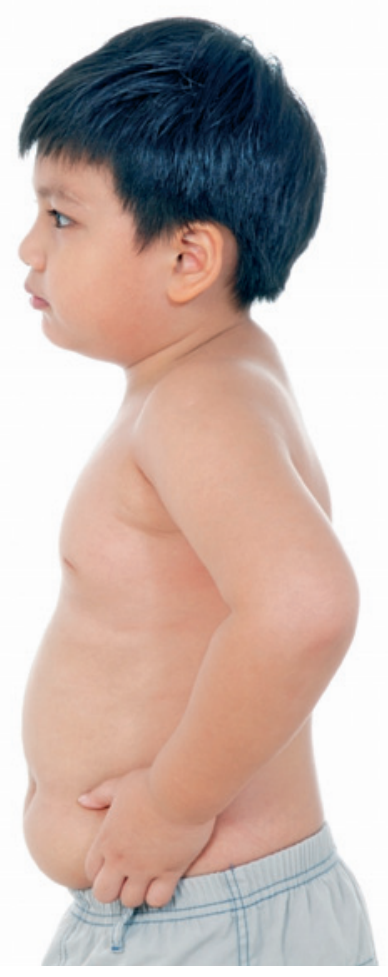

Illustrasjonsfoto Istockphoto 